Université d'Abidjan: Nouvelles de la Recherche (voir aussi Africa, xxxix, I, 1969, pp. 72-3)

Institut d'Ethno-sociologie

H. Memel-Fôtế: l'enquête sur le système politique traditionnel des Adjukru (souspréfecture de Dabou), commencée en octobre 1965, se poursuivra jusqu'en mai 1969 et on espère la publication dans le courant de 1970; $A$. Ferrari $i$ l'étude sur le centre semi-urbain de Lakota se poursuit avec la collecte des données sur les changements économiques affectant l'agglomération, l'évolution de la population féminine, et les traits caractérisant aujourd'hui la classe des adolescents; E. Terray: L'organisation sociale des Dida de Côte d'Ivoire est en cours de publication (Annales de l'Université d'Abidjan, série Ethno-sociologie).

Institut de Linguistique Appliquée

G. Dumestre: un atlas linguistique de Côte d'Ivoire et l'étude d'une des variétés de Dioula; L. Duponchel: l'étude de l'Alladian; J. Le Saout: la langue des Gagou; G. Hérault: l'étude de l'Adioukrou; G. Retord: l'Agni-Sanvi; $A$. Ouinde et $P$. Kokora (chercheurs extérieurs à l'Institut): le Tagbana et le Koyo.

\title{
An Association of Africanists in Germany
}

ON the initiative mainly of the more junior German Africanists, an Association of Africanists in Germany (Vereinigung von Afrikanisten in Deutschland-VAD) has recently been formed. Dr. Hermann Jungraithmayr, University of Marburg, has been elected Secretary. The aims of the association are to facilitate communication between research workers and teachers in the field of African studies, whether affiliated to a university or not; to provide assistance in projects involving co-operation between different disciplines; to make contact with foreign scholars and institutions in Europe and Africa; and to provide information for the German public about the development of African studies in Germany and the work of the association. Regular activities will include an annual conference, the first of which was held at Marburg from 18 to 20 July 1969 on 'Problems and potentialities of inter-disciplinary co-operation in the field of African studies'. It is hoped to publish the proceedings of these conferences in a special series.

\section{The Centre for African Legal Development (Centre de Développement juridique africain)}

THIs Centre has been established within the Faculty of Law, Haile Sellassie I University, Addis Ababa. Its programme includes the collection of African legal materials and their diffusion to interested persons, the production of selected documentation on the development of African law in various fields, and the holding of seminars for teachers of law and courses for post-graduate students on comparative African legal development. It is also publishing books and organizes conferences.

The Centre has received financial assistance from the Ford Foundation and the Belgian Government which has enabled it to engage academie and technical staff to equip a complete micro-copying laboratory. The Haile Sellassie I University and the Free University of Brussels are co-operating on the African Law Bibliography Project and the African Legislation Protect, both of which should be completed in 1972. The former is now completing the African Lan Bibliography $1947-66$, which includes references to all books and articles on African law published from 1947 to $x 966$, and yearly supplements will be prepared in conjunction with the African Law Department, SOAS, University of London; the first 